\section{SOI: $1.1 /$ TAS $\quad$ DOI: $10.15863 /$ TAS International Scientific Journal Theoretical \& Applied Science}

\author{
p-ISSN: 2308-4944 (print) e-ISSN: 2409-0085 (online) \\ Year: 2015 Issue: 03 Volume: 23 \\ Published: $30.03 .2015 \quad$ http://T-Science.org
}

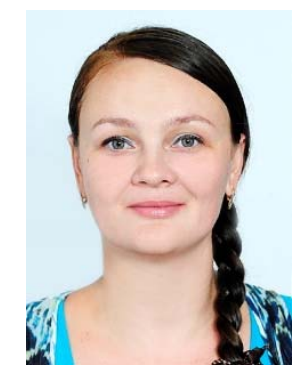

Oksana Andreevna Maletina Candidate of Philological Science, Assistant Professor of the Department of professional foreign language communication, Volgograd state university, Russia okmaletina@yandex.ru

SECTION 21. Pedagogy. Psychology. Innovations in the field of education.

\title{
ELECTIVE COURSES AND OLYMPIADS AS A PART OF PROFILE EDUCATION UNDER NEW ECONOMIC CONDITIONS
}

Abstract: The article conveys the connections between profile education, elective courses and Olympiads. The main goal of the profile education is to create a system of the specialized preparation of senior pupils in order to individualise education and to help pupils' socialization taking into account real demand of the labour market. Profile education aims at changing structure, content and organization of teaching process taking into consideration interests, inclinations and abilities of pupils in accordance with their professional interests and intentions to continue their education. Under new economic conditions when it's very difficult to find a well-paid and interesting job, pupils will be ready to make the right choice and will have the opportunity to enter universities according to their interests and inclinations thanks to elective courses and Olympiads.

Key words: profile education, elective courses, Olympiads, graduates, abilities, inclinations, senior pupils, profound study.

Language: English

Citation: Maletina OA (2015) ELECTIVE COURSES AND OLYMPIADS AS A PART OF PROFILE EDUCATION UNDER NEW ECONOMIC CONDITIONS. ISJ Theoretical \& Applied Science 03 (23): $37-40$.

Soi: http://s-o-i.org/1.1/TAS*03(23)7 Doi: crossef http://dx.doi.org/10.15863/TAS.2015.03.23.7

\section{Introduction.}

New economic conditions force employers to hire employees who are flexible to change and have good education, that's why high school graduates have difficulties in choosing their future profession. Their decision influences their future employment and school has to help its graduates to choose future profession according to their abilities and interests. There are schools with profound study of some subjects - lyceums and gymnasiums, but it's very difficult to enter such schools because of the rigorous selection. Any comprehensive school always devoted so little time to career-guidance, so more than half graduates didn't even imagine what they were going to be and where to study. Other pupils prepared to enter universities with tutors, because there was no opportunity to get knowledge at schools. Now the situation is changing thanks to the profile education.

The aim of the work is to analyse the connections between profile education, elective courses and Olympiads.

The object and methodology of research.
To achieve this goal, we have identified the following interdependencies: profile education $\rightarrow$ elective courses $\rightarrow$ Olympiads. The object of the research is the system of the profile education.

The results of the research and their discussion.

Olympiads and elective courses as a part of the profile education contribute to the development of certain abilities of pupils. According to the statistics over $60 \%$ of pupils, who study at elective courses, enter universities, and $24 \%$ enter colleges [11].

The main goal of the profile education is to create a system of the specialized preparation of senior pupils in order to individualise education and to help pupils' socialization taking into account real demand of the labour market. Profile education aims at changing structure, content and organization of teaching process taking into consideration interests, inclinations and abilities of pupils in accordance with their professional interests and intentions to continue their education [2, p. 187-192].

Since the main aim of the profile education is to individualise education taking into account 
professional interests of pupils, the main tasks are the following:

1) to provide profound study of particular subjects;

2) to create conditions of differentiation of the education content;

3) to help pupils of different categories to get good education;

4) to extend potential of pupils' socialisation and to provide succession between general and professional education;

5) to prepare graduates to study effectively at universities.

Thus profile education helps pupils to choose priority field for deeper study, and the selection means variability of the education. The profile has three components: core general subjects which are obligatory for all pupils; profile general subjects; elective courses [3, p. 162-167].

Preprofile preparation should begin in the eighth and ninth forms with the study of any subject at elective courses, where teacher finds special material for profound study, recommends textbooks and probably scientific journals, online resources [4, p. $258-263]$. The final product of elective courses depends on the specificity of the studied subject and may include project, reports at different conferences, presentation, taking part in Olympiads and so on. Let's consider Olympiads of foreign languages.

According to the normative documents there are four types:

I type - school $(01.10-15.11)$; 15.12);

II type - municipal: district Olympiads (15.11 -

III type - regional $(10.01-10.02)$;

IV type - final $(20.03-01.05)[6$, p. $422-$ 428].

Thus pupils from 5-11 forms take part in school Olympiads, it's necessary to point out that only pupils with good and excellent marks can do Olympiads' tasks. But if we take real situations, we can have the following: teachers are given Olympiads' tasks and asked to have the results by the end of the lessons. So teachers are in a hurry and their attitude is the same. To be honest, schools' marks are always subjective, because teachers' portfolio depends on their pupils, that's why excellent and good marks don't show the true level of pupils' knowledge. So pupils, who are constantly training with tutors, always have excellent results, but school teachers didn't help to achieve this level of knowledge. But when pupils win, of course, schools include these achievements in their rating, because these victories influence their salary. But all the same talented pupils have the chance to take part in such Olympiads, probably win and be noticed.
Participants of school Olympiads, who have the maximum number of points, are considered winners. If we consider such situations, when teachers are devoted to the profession and ready to spend their time to prepare their pupils to take part in school Olympiads, how can schools help them? And we return to the profile education, because it allows pupils to get additional and more profound knowledge, and teachers are paid for their work. So we have the following scheme: profile education $\rightarrow$ elective courses $\rightarrow$ Olympiads.

If schools are interested in finding talented pupils, and in their turn they stimulate their teachers to do this work, pupils have the opportunity to get more profound knowledge which will help them in their future profession. Thus interested teachers and motivated pupils are ready to create a group of people who are eager to work hard and are oriented to get a result. This group will allow to share the experience between pupils and to get a psychological training. Teachers have to motivate pupils since they are in the primary school. In senior school they will be ready psychologically to choose subjects for profound study and they will understand what they are interested to do in the future.

Profile education is a specialized system of teaching pupils of senior school to provide choice of their professional activity. This choice assists pupils to realize what abilities they have and what interests them. This profile preparation will help pupils to enter institutions of higher education, because they will not have any difficulties in choosing their future profession [5, p. 382-388].

As profile education means the variability of the education, elective courses are the component of this variable part of the education content. These courses are the most important means of creating individual education programmes, because they are connected with individual choice of subjects which reflects pupil's interests and inclinations.

When teachers found pupils with special interests in English, they can create a group to attend elective courses. As we mentioned, the final product of these courses can be different, but we are going to consider how to prepare talented pupils to win at Olympiads.

Let's look at tasks which are always included in Olympiads. These tasks are reading, listening, use of English, writing and speaking. If we compare these tasks with tasks of the Unified National Exam, we will see that they coincide. Thus when we teach pupils how to do tasks of Olympiads, we will teach them how to pass the Unified National Exam, and we will achieve our goal of the profile education.

Thus the first task is reading, and it always includes reading the text and finding the appropriate answer which suits better: 
1) You are going to read a newspaper article in which people talk about where they played as children. For questions 10-15, choose from the people (A-G), and for questions 16-24, choose which person's play area $(A-G)$ is referred to. The people and play areas may be chosen more than once. When more than one answer is required, these may be given in any order. There is an example (0).

2) For items 1-10 read an article about English place names. Fill in the gaps in the table, using the information from the text [1].

Reading may also include the following tasks:

1) Find the best item to fill each gap. Use each item once only.

2) Complete the table using the text.

Listening is always connected with matching: You'll hear 6 people talking about recent experiences they have had. Match what you hear from each speaker 1-6 with the statements marked A-G. Use letters once only. There is an extra statement you don't need to use. You'll hear the recording twice. Fill the boxes in the table with your answers [9].

Use of English may consist of the following tasks:

1) For questions 1-15 complete the following article by writing each missing word in the correct box on your answer sheet. Use only one word for each space.

2) For questions 16 - 20 choose the best alternative $A$ or $B$.

3) For questions 21 - 25 replace the words in italics with a suitable phrasal verb from the box below. There are three extra phrasal verbs, which you do not need to use.

Writing includes creating an essay: for example, under the title 'Dos and Don'ts' to attract attention of young people to the problems of health. Participants should give practical and valuable advice to follow in order to stay healthy $[10$, p. $35-$ 61].

When teachers teach pupils how to pass Speaking successfully, it's necessary to pay attention to forming questions in monologues and giving correct answers to questions of different types. Usually Speaking has two tasks: monologue and dialogue. If we look at the examples, we may notice that they are formed to check social competence.

\section{Task 1}

(Monologue)
In a minute you will have to speak about the importance of smells in our life. What information can smells carry/ bear? What is so special about them for you and other people?

Task 2

(Dialogue)

Imagine that you and your partner are students at a university. Discuss with your partner the best living conditions for student life at the university. Your role is to be in favour of living in a university dormitory on campus rather than with one's parents. Give arguments and examples in support of your opinion. You may or may not come to an agreement with your partner. Remember it is a discussion and not a monologue.

Your answers will be recorded [3, p. $35-61]$.

So all the tasks of Olympiads are aimed to check the level of pupils' preparation to their final exam at school. The readiness to pass the exam excellently means the right choice of the future profession.

Hence organisators of Olympiads should:

$>$ popularize scientific knowledge and develop the interest to the scientific activity;

$>$ create conditions to detect talented pupils;

$>$ intensify the work of elective courses;

$>$ assist senior pupils to choose their profession according to their interests and inclinations.

\section{Conclusion.}

The success of this work depends on teachers and pupils, so they should work together to achieve these goals. If teachers manage to interest their pupils, then they should work hard in order not to lose this interest. So the success of the profile education includes the work of schools, teachers and pupils, that's why teachers should become not only tutors but mentors. Teachers teach pupils not only to win but they teach how to lose and to be ready that someone else will know more or be prepared better. These expectations will help to form a creative personality who will be ready to work successfully in different fields. Thus under new economic conditions when it's very difficult to find a well-paid and interesting job, pupils will be ready to make the right choice and will have the opportunity to enter universities according to their interests and inclinations thanks to elective courses and Olympiads. 


\section{References:}

1. Kopylova VV (2009) Vserossiiskaya olimpiada shkol'nikov po angliiskomy yazyku. $8-11$ klassy. Moscow: Drofa.

2. Maletina OA (2010) Profil'noe obuchenie v novykh ekonomicheskikh usloviyakh. Nauka. Kul'tura. Obrazovanie. Aktual'nye problem i perspectivy razvitiya. Volgograd: Volgogradskoe nauchnoe izdatel'stvo, pp. 187192.

3. Maletina OA (2010) Profil'noe obuchenie V novykh ekonomicheskikh usloviyakh (postkrizisnoe obrazovanie). Aktual'nye problemy kommunikacii i kul'tury. Vyp. 12. Moscow-Pyatigorsk: Pyatigorskii gosudarstvennyi lingvisticheskii universitet, $\mathrm{pp}$. 162-167.

4. Maletina OA (2010) Profil'noe obuchenie v usloviyakh modernizacii regiona. Problemy modernizacii regiona $\mathrm{v}$ issledovaniyakh molodykh uchenykh. Volgograd: Volgograd state university, pp. $258-263$.

5. Maletina OA (2012) Metodicheskie pekomendacii po podgotovke shkol'nikov $\mathrm{k}$ uchastiyu $\mathrm{v}$ olimpiadakh po inostrannomu yazyku. Sovremennye problemy lingvistiki i lingvodidaktiki: koncepcii i perspektivy. Volgograd: Volgograd state university, pp. 382-388.

6. Maletina OA (2013) Olimpiady i elektivnye kursy kak podderzhka odarennykh detei.
Sovremennye problem lingvistiki i lingvodidaktiki: koncepcii i perspektivy. Volgograd: Volgograd state university, pp. 422 $-428$.

7. Maletina OA (2013) Onlain-resursy kak sredstvo intensifikacii uchebnogo processa $\mathrm{V}$ praktike obucheniya inostrannomy yazyku. Kommunikativnye aspekty lingvistiki i lingvodidaktiki, Volgograd: Volgograd state university, pp. 637-640.

8. Maletina OA (2014) Uchebno-issledovatl'skaya deyatel'nost' kak sredstvo razvitiya uchenikov srednei shkoly. Sovremennye problemy lingvistiki i lingvodidaktiki: koncepcii i perspektivy. Volgograd: Volgograd state university, pp. 157-161.

9. Sigal TK (2004) Gotovimsya k olimpiadam po angliiskomu yazyky. Moscow: Airis-Press.

10. Ter-Minasova SG, Kurasovskaya YB (2011) Metodicheskie rekomendacii po razrabotke zadanii dlya shkol'nogo i municipal'nogo etapov vserossiiskoi olimpiady shkol'nikov po angliiskomu yazyku v 2011/2012 uchebnom godu. Moscow, pp. $35-61$.

11. Upravlenie obrazovaniya admistracii g. Tula. (2013) Available: http://www.uotula.ru/cgibin/index.cgi?id=60 (Accessed: 01.03.2013). 